\title{
Marketing of organic products in southern Poland
}

\author{
Maciej Kubońn ${ }^{1 *}$, Elżbieta Olech ${ }^{1}$ \\ ${ }^{1}$ Department of Production Engineering and Power Energy at the University of Agriculture in Kraków, Poland
}

\begin{abstract}
The article presents an outline of the issue concerning formulation of a marketing strategy and the possibility of using the knowledge on consumers' preferences for organic development of farms and their products on the example of southern Poland. The paper analyses the distribution process of organic food in the aspect of developing innovative marketing strategies. The studies were performed in 50 organic farms and on the example of 100 respondents from the region of southern Poland. In the opinion of the surveyed representatives of the organic food producers, a competitive advantage of their offer depends the most on the health values, brand, reputation, and taste. Moreover, information on products and the form and place of their sale are significant. The analysis shows that the knowledge is the most eagerly obtained from the Internet. Thus, producers should publish their profiles and pages on social media and business portals.
\end{abstract}

\section{Introduction}

Over the years, a significant growth of some types of products in the food marketing has been observed. This long-term trend, with a varied degree of advancement with regard to the market, concerns, inter alia, functional, health, regional, traditonal and organic products [3]. Development of the organic products market has taken place as a result of the impact of many factors and events on the market, among others, food scandals, which caused that consumers choose natural products. They care more for the environment and health, they return to nature, which results in purchaserelated decisions [4]. A raising demand for organic food is one of the components of deeper changes which take place in the modern consumption model [12, 15]. Numerous domestic and foreign research confirm development of purchase behaviour on the organic production market. Consumers' behaviour with regard to these products depend on various factors. They are mainly determined by the level of organic awareness, income level, knowledge level and marketing operations $[8,11,13,16]$. The research carried out in Great Britain proved that the care for food safety is the most insignificant determiner in relation to organic products as well as it confirmed the significance of the ethical stand of consumers in this context [2]. The marketing mix specificity for organic food may be analysed at the global level [9]. Obtaining the quality certificate triggers the success on the organic products market [1]. According to A. Graczyk and K. Mazurek-Łopacińska development of these markets in Europe is activated by accepting the sustained development strategy of the EU, realization of which depends on cultural factors [6]. In Poland, one can also observe a dynamic increase of the number of producers producing food with organic methods. In 2012, the number of organic food producers was 26376 (including 312 food processing plants) and for comparison in 2011 - 23847 (including 270 food processing plants) [9]. B. Pilarczyk and R. Nestorowicz show that the organic food market in Poland is at the initial stage of development and entities acting on this market only slightly utilize the experience of marketingoriented enterprises $[10,17]$. An agricultural producer, in order to successfully participate on the European market, must participate in pro-development activities, i.e. inter alia: active marketing, trainings, education, participation in fairs or implementation of innovative processes. Finally, agricultural farmers in Poland who want to obtain a high competitive position on the European market, must, first of all, have a wide range of operations which enable a continuous distribution of own products $[5,7,18]$. Organic food is not easily found in usual shops and distribution centres. Indeed, specialist shops with organic food and their networks are established but it takes place only in big cities. However, the scale of these activities is still too small to increase the sales in Poland. Certainly, high prices of organic products in comparison to traditional food impede obtaining wider consumers' interest $[15,17]$. Thus, the need to implement a strategy that aims at improvement of conditions and facilitation of sale has occurred. Marketing strategies, which constitute a whole comprising price strategies related to each other, product strategies, distribution strategy and promotion strategy are examples of such actions[16]. The strategy elements form an integrated market operations system which ensures the enterprise with a competitive position. One of important elements of marketing, from which designing marketing strategies takes place, is a good, namely a product. The product should be attractive so that the consumer may maximize the sum of satisfaction

Corresponding author: maciej.kubon@ur.krakow.pl 
and advantages related to owning and consumption[17, 18 , 19]. Having a product should thus provide a consumer with a relevant level of satisfaction, profit and credible image on the market for the enterprise. In order to undertake an initiative related to implementation of marketing strategies, the first step is to know the client's preferences concerning the product itself and elements related thereto such as the packaging form, preferred form of sale or the motive behind the selection of a given product.

\section{Objective, methodology and scope of research}

The objective of the research was to analyse the organic food distribution process through the prism of consumer's preferences towards the process in the south Poland region. Knowledge on them gives a chance to prepare suitable channels and develop a relevant marketing approach. In order to achieve this aim, a guided survey was made for the clients from the selected area and organic food farms were investigated. The investigated population included a mixed sample of 100 people and the number of investigated organic farms was 50. The prepared survey included questions which give the opportunity to collect information related to financial possibilities of families which they may designate for the purchase of organic food, frequency of consumption, properties which influence the selection of the product as well as a preferred form of sold products and packagings for organic food. Knowing this information will enable adjusting the production structure and the product itself to specific consumer's requirements and thus improvement of distribution channels and broadening the knowledge within this range in order to develop a relevant marketing strategy. The collected information was obtained on the basis of a guided survey carried out with a farm owner and randomly selected group of responders. The collected data allowed determination of the production size and structure of sale of organic products and clients' preferences at the purchase of organic products. The global production value was assumed as a sum of plant production, animal production produced in the production process and sold services and the commodity production value as a sum of agricultural production sold by a farm.

\section{Characteristics of the investigated population}

All respondents knew the concept of organic food. Majority wants these products to be more available on the market. From among the surveyed persons, 54\% were women and $46 \%$ were men. The most numerous age group consisted of people within the age of 26-35 i.e., $33 \%$ of the respondents. People above 45 were the most numerous group - $11 \%$. With regard to the financial situation of the households, the questioned respondents were divided into two groups. The first one $(58 \%$ of respondents) admits that their financial situation is average namely the monthly gross income does not exceed PLN 3 thousand, while $42 \%$ declares that it is good, i.e., income per a family exceeds PLN 3 thousand. With regard to education, the biggest group of respondents included people with secondary school education - 52\% and above $70 \%$ of respondents are people who are employed and have children.

\section{Research results}

A fast civilization progress and social requirements cause the necessity of extending the economic growth and satisfaction of people's needs. Furthermore, eating habits of citizens of particular countries as well as the food consumption structure depend mainly on the environmental conditions, which take place in the place of residence, tradition and the degree of economic development of the country and related financial resources of the society.

Analysis of the global markets shows that presently the organic food market is one of the most developing food markets in the European Union. This food more and more often becomes a substitute of the traditional food. For several years, the increase in the number of organic food shops can be observed. The Internet has become the most frequently chosen form of organic food purchasing. Following the example of other countries, it is necessary to develop detailed characteristics of the organic food buyer. It aims at providing entrepreneurs with this knowledge, so that they can precisely adjust their products to consumer's expectations. This characteristic should present specific consumers' preferences including organic production so that, recommendations, which will concern the possibilities of use and extending an offer on the market should be prepared. It should result in the increase of competitiveness and sale of organic products.

When mentioning competitiveness it should be emphasised that nowadays, it is strongly developed and depends on the consumers' changing needs and requirements. Proper adjustment of the market assortment to consumers' requirements may ensure demand on products as well as the increase of the enterprise competitiveness.

Organic farms in Małopolska region feature high distribution of the agrarian structure as well as production structure. It can be translated into the production scale and that on the size of commodity production which basically influences the farm income amount. Table 1 presents a unit value of organic production divided into production divisions.

Table 1. Unit value of organic production divided into production divisions.

\begin{tabular}{|c|c|c|c|c|c|c|c|}
\hline \multirow{3}{*}{$\begin{array}{l}\text { Farm } \\
\text { group }\end{array}$} & \multirow{3}{*}{ Parameter } & \multicolumn{6}{|c|}{ Production } \\
\hline & & \multicolumn{2}{|c|}{ Plant } & \multicolumn{2}{|c|}{ Animal } & \multicolumn{2}{|c|}{ Total } \\
\hline & & Global & Commodity & Global & Commodity & Global & Commodity \\
\hline
\end{tabular}




\begin{tabular}{|c|c|c|c|c|c|c|c|}
\hline & & PLN'ha ${ }^{-1}$ & $\%$ & PLN'ha ${ }^{-1}$ & $\%$ & PLN'ha ${ }^{-1}$ & $\%$ \\
\hline \multirow[b]{2}{*}{ Total } & average & 5008.4 & 78.3 & 2626.9 & 79.5 & 7635.3 & 78.7 \\
\hline & $\begin{array}{l}\text { standard } \\
\text { deviation }\end{array}$ & 6962.2 & - & 3027.2 & - & 6908.6 & - \\
\hline \multirow[b]{2}{*}{ up to $5 \mathrm{ha}$} & average & 7526.6 & 85.4 & 2110.4 & 72.9 & 9636.8 & 82.7 \\
\hline & $\begin{array}{l}\text { standard } \\
\text { deviation }\end{array}$ & 8486.5 & - & 2067.4 & - & 8811.2 & - \\
\hline \multirow[b]{2}{*}{$5.01-10.00$ ha } & average & 3856.7 & 64.6 & 3108.3 & 81.2 & 6965.0 & 72.0 \\
\hline & $\begin{array}{l}\text { standard } \\
\text { deviation }\end{array}$ & 3498.5 & - & 4176.8 & - & 4959.5 & - \\
\hline \multirow[b]{2}{*}{$10.01-20.00$ ha } & average & 7497.3 & 91.7 & 1503.2 & 79.5 & 9000.5 & 89.6 \\
\hline & $\begin{array}{l}\text { standard } \\
\text { deviation }\end{array}$ & 10043.1 & - & 2108.4 & - & 9231.5 & - \\
\hline \multirow[b]{2}{*}{ area 20.00 ha } & average & 1425.0 & 20.8 & 3640.6 & 83.2 & 5065.6 & 64.1 \\
\hline & $\begin{array}{l}\text { standard } \\
\text { deviation }\end{array}$ & 1060.1 & - & 1919.8 & - & 1932.4 & - \\
\hline
\end{tabular}

Source: Kuboń, et al. 2014

The total commodity production in the investigated farms was $6009.73 \mathrm{PLN} \cdot \mathrm{ha}^{-1}$, which constituted at the average $78.7 \%$ of the global production. The commodity production in the group of objects from 5-10 ha was at a comparable level. In comparison to these objects, in the group of farms from $10-20$ ha the commodity production was higher by 4 and $11 \%$ and in the biggest farms (area of $20 \mathrm{ha}$ ) - it was lower by almost $15 \%$. Whereas, taking into consideration production departments, it was reported that the animal commodity production $(79.5 \%)$ slightly prevailed over the plant commodity production $(78.3 \%)$. The highest participation of animal commodity production occurred in the group of farms with the area of 20 ha $-83.2 \%$ and the lowest up to 5 ha $-72.9 \%$

Distribution next to production is one of the most important elements in the logistic chain. Its main task is making the product available in place and time corresponding to the clients' needs and expectations. From the point of view of macroeconomics, distribution means the process and structure of moving goods from producers to target consumers. Thus, it constitutes a selected group of market channels and connections between them. Distribution systems of a particular organization structure and equipped with materialtechnical factors, which exist in economy, create conditions, which constitute the basis for selection of the manner of relocating products from the production zone to the consumption zone. Features of these systems cause that in a short period, they become an external factor for shaping ways of distribution. Decisions related to selection of the sale manner are included in each enterprise to strategic decisions, because they finally influence effectiveness of market activities and achieved economic effects [7].

Producers of organic food products should pay attention more often to the changes of consumers' likings and preferred manners of satisfying food needs, e.g. a demand for the so-called convenient food products, partially or totally ready for consumption and also to the need of manufacturing new products. This, on the other hand requires the use of new technologies, adjusted to the existing legal regulations with regard to the organic farming.
A requiring outlet of agricultural products forces organic food producers to numerous activities which aim at obtaining new and maintaining regular customers. Presently, it is very difficult, because, the present market provides a richer offer of products of foreign origin. Only thorough research of client's needs will create a demand for specific products and will allow loyalty to a known product. It should be also emphasised that consumers' awareness rising every year is reflected in the demand for goods which differ with original recipe, which results from the search of extraordinary composition.

A modern consumer, taking up a decision on the purchase of food, becomes more requiring, thus a relevant price and the standard quality does not suffice. A choice of products with suitable parameters, in particular the most important are: taste and health values, popular brand, production tradition, regional origin, more strict control of the production process, is a basic issue which has become more significant for the potential client.

Taking into consideration the criterion, namely, the form of organic products packaging, respondents preferred to buy loose products, in small packaging or in sealed containers. Women aged $26-35$ prefer to buy loose products because of a wider choice of products. They are also interested in a small packaging within 1-2 kilo. A trend among men was similar. Respondents aged 18-25 were interested in the purchase of loose products or with a small weight - up to 2 kilo, and in products in sealed containers because of a longer shelf life of such products. Figure 1 presents preferred forms of organic products. 


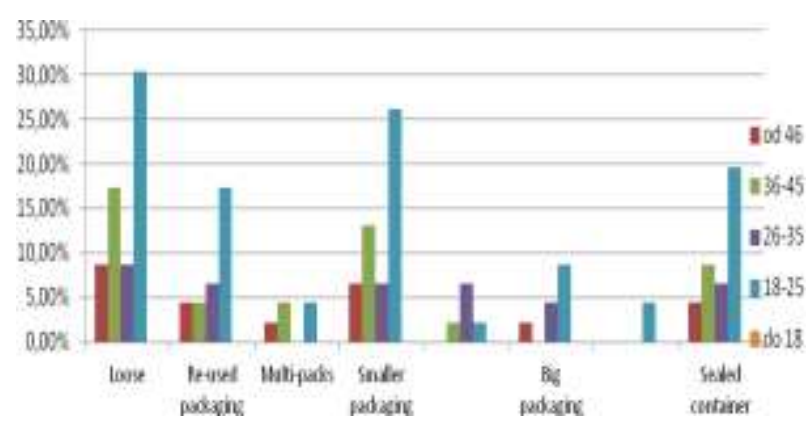

Fig. 1. Form of organic products packaging.

In case of the Poland's region it is difficult to talk about an organized sale of organic food products. Direct sale of organic food and sale through specialised channels, which is characteristic for the initial phase of the market development, prevails. Contrary to the Western Europe countries, in Poland, there is a small number of specialist shops (ca. 250) with a small variety of products. An insufficiently developed indirect sell is an additional weakness (number of specialistic warehouses is about 30) [14].

Basic information, significant for producers in order to develop marketing strategies consist of: sources of information on organic products, motive of selection and place of purchase of organic products. Knowing answers to those and other questions, they will be able to prepare a suitable marketing or promotional campaign.

Taking into consideration the age criterion in acquisition of knowledge on organic food, the Internet was prevailing both among women and men. Women within 26-35 years of age and 36-45 prefer searching for information on products in the Internet. Number of these answers exceeded 30\%. However, among women information from press and radio is also valuable. The highest number of such answers was given by people aged 18-25 and 36-45. Men in the age of 18-45, similarly to women, obtain information on organic food most often in the Internet. Studies proved that this is the main source of obtaining information on organic products.

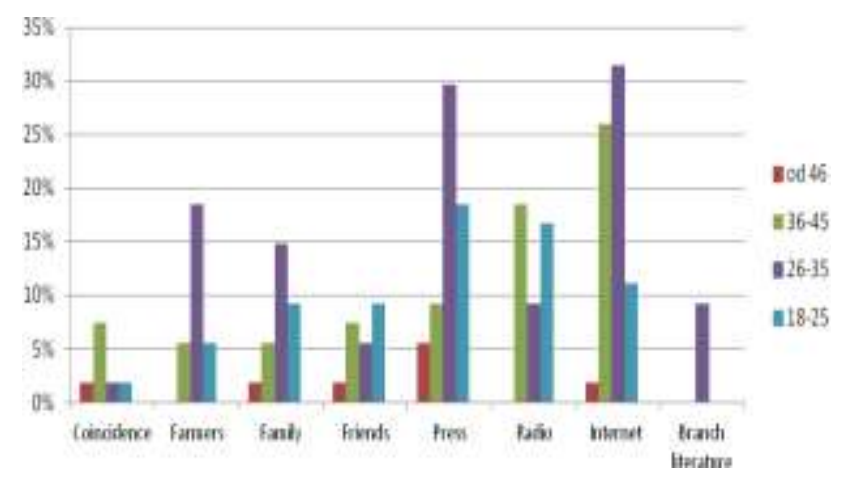

Fig. 2. Sources of knowledge on organic products in relation to age.

Clients' motives for choosing organic food are other significant factors. Women in the age 36-45 mentioned a popular source as the main motives for choosing organic food, no hazardous substances and low processing of products. More than $30 \%$ of respondents provided such answer. While, women aged 18-25 years mentioned known sources and no preservatives and dyes as the main motive of selection of an organic product. For men aged 26-45 it is the most important that organic food was without preservatives and dyes and it was rich in nutrients and processed to a small scale. It is also important that food has high taste values. Men, aged above 46 value such features as: no preservatives and dyes and the fact that it is rich in nutrients.

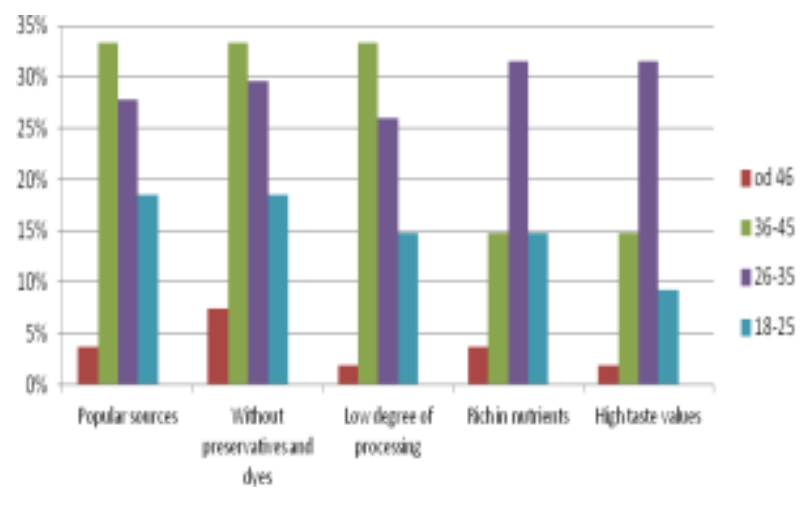

Fig. 3. Motives of choice of organic food.

With regard to the place of purchase of organic food, the most often women bought organic food at the healthy food stand of the shop - over $20 \%$ of answers in the age group 26-35. In that age group responses indicated that they also make shopping in healthy food shops and directly at a producer. Women do online shopping more rarely than men. A higher variety at a selection of the place of purchase was reported in case of men. The most often they buy at healthy food stands. Men aged 18-25 also often buy directly at a producer as well as in the Internet. Men aged 26-35 and above 46 years value also shopping in healthy food shops.

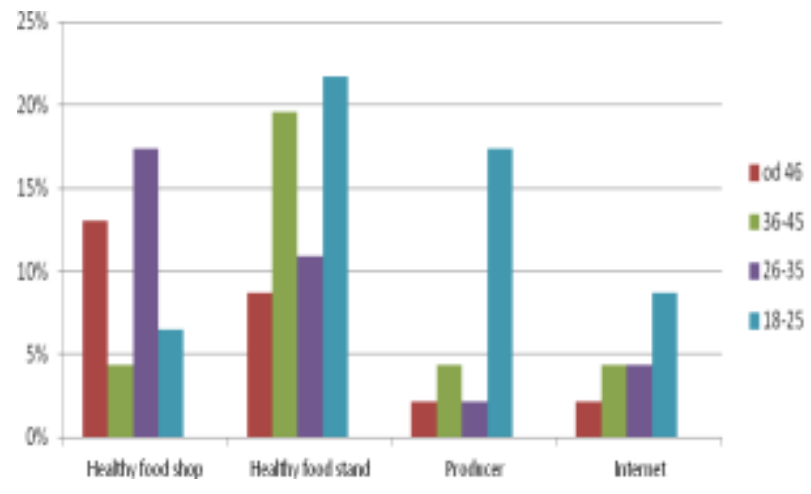

Fig. 4. Preferred places of organic food purchase.

With reference to the organic food purchase for all surveyed people, a price is important but according to the research, other factors also play a significant role. All mentioned properties are more or less important for respondents. For women aged 26-35 the product composition and its smell - $25 \%$ and for women aged above 46 the shelf life, composition and labelling is 
important. Women pay less attention to the product appearance. Men indicated smell as one of the most important factors - over $35 \%$ of responses in age groups 18-25 and 26-35. The product composition and shelf life are important in the age group 18-25. Appearance is less important. Men decided that the least significant feature is product labelling.

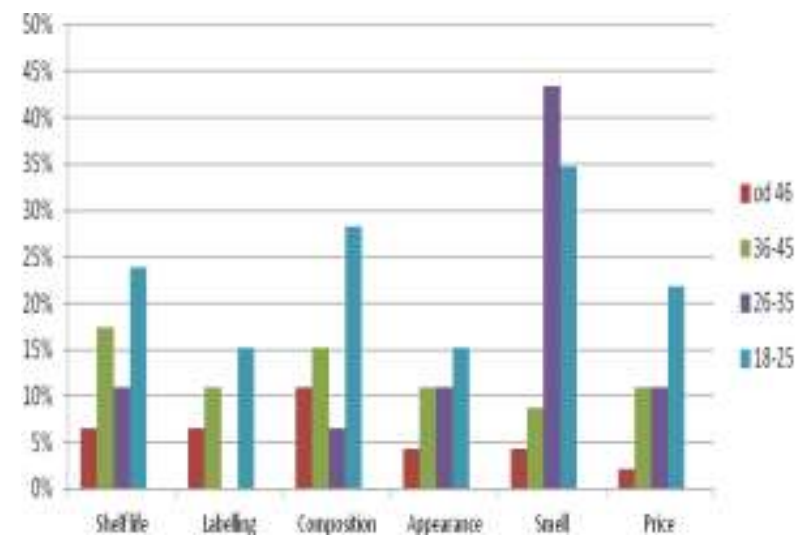

Fig. 5. Product features which determine its purchase.

\section{Conclusions}

In order to develop new distribution channels or marketing strategies of organic food sale, a periodical market analysis is necessary, especially if their main element is recognition of clients' needs and requirements. Results of such analysis are a great support for producers because they provide necessary knowledge which enables orientation of production to specific requirements, finding a production niche, and thus to be more competitive among other producers.

Authentic quality values of a product favour implementation of the marketing principles in the organic food sector. However, according to the theory, the product itself is not sufficient to become successful on the market. Except for relevant pricing, the product must be delivered optimally to the places of sale (distribution) and the customer must be informed on its values and encourage to buying (promotion).

In the opinion of the surveyed representatives of the organic food market, a competitive advantage of their offer depends the most on the health values, brand, reputation and taste. Current provision of information on products is also important. The analysis proves that such knowledge is the most eagerly obtained from the Internet because presently a majority of people in their free time broaden their knowledge by reading information on webpages. With reference to the entrepreneur's marketing they should publicise their profiles on social media pages and business portals.

Higher ecology awareness of producers and consumers may help to extend organic production and distribution of their products in Poland. Suitable application of the market research may support producers in extending their offer and enable fighting over outlets through adjustment of their behaviour and the product to the consumer's preferences.

\section{References}

1. K. Achilleas, S. Anastasios, British Food Journal, 8, 110, 829 (2008)

2. N. Michaelidou, L. Hassan, International Journal of Consumer Studies, 32, 163 (2008)

3. M. Strumioska-Kutra, Ekologiczna świadomość Polaków. Analiza wyników badań ilościowych z lat 1992-2011, Instytut na rzecz Ekorozwoju, Warszawa (2012)

4.S. Żakowska-Biemans, British Food Journal, 1, 113, 122 (2011)

5. G. Wójcik, Wiadomości Zootechniczne, 2, 29 (2012).

6. A. Graczyk, K. Mazurek-Łopacińska, Badanie rozwoju rynków produktów rolnictwa ekologicznego $i$ żywności ekologicznej w Polsce. Wydawnictwo Uniwersytetu Ekonomicznego we Wrocławiu, Wrocław (2009)

7. M. Kuboń D. Kwaśniewski, U. Malaga-Toboła, S. Tabor, Agricultural Engineering 2 (150), 77 (2014)

8.B.J. Phillips, E.F. McQuarrie, W.G. Griffin, Psychol. Mark. 31, 225 (2014)

9. L. Witek, Handel Wewnętrzny 1 (354) 281 (2014)

10. B. Pilarczyk, R. Nestorowicz, Marketing ekologicznych produktów żywnościowych. Wolters Kluwer Polska, Warszawa (2010)

11. C. Prentice, J. Chen, X. Wang, Journal of Retailing and Consumer Services (2017) - article in press

12. B. Chekima, A. I. Oswald, S. A. Wafa, S. Wafa, K. Chekima, Journal of Cleaner Production 166, 1438 (2017)

13. Q. Zhu, J. Sarkis, Int. J.Production Economics 181, 289 (2016)

14. W. Łuczka-Bakuła, J. Smoluk-Sikorska, Journal of Research and Applications in Agricultural Engineering, 55(4), 12 (2010)

15.A. Szeląg-Sikora, M. Cupiał M. Niemiec, Agriculture and Agricultural Science Procedia, 7, 94, (2015)

16. A. Szeląg-Sikora, M. Cupiał, M. Niemiec, Agriculture and Agricultural Science Procedia. 7, 249 (2015)

17. A. Szeląg-Sikora. M. Niemiec, J. Sikora. Journal of Elementology, 21, 3. 915 (2016)

18. Z. Gródek-Szostak, A. Szeląg-Sikora, J. Sikora, M. Korenko Business And Non-Profit Organizations Facing Increased Competition And Growing Customers' Demands, 16, 427, (2017)

19. M. Kołtun, S. Kocira, Z. Krzysiak, M. Ćwiklińska A. Kocira, M. Koszel, Agriculture and Agricultural Science Procedia 7, 113 - 118, (2015) 